\title{
Detect to protect: pneumoperitoneum gas samples for SARS-CoV-2 and biohazard testing
}

\author{
Enrico Cicuttin ${ }^{1,2} \cdot$ Lorenzo Cobianchi $^{1,2}\left(\right.$ Massimo Chiarugi $^{3} \cdot$ Fausto Catena $^{4} \cdot$ Federico Coccolini $^{3}$. \\ Andrea Pietrabissa ${ }^{1,2}$
}

Received: 25 April 2020 / Accepted: 28 April 2020 / Published online: 4 May 2020

(c) Springer Science+Business Media, LLC, part of Springer Nature 2020

As we walk through a period of uncertainty, it becomes essential to obtain clear, prompt, and evidence-based indications to guide surgeons and protect OR staff. The SARSCoV-2 pandemic profoundly modified the patients' case load of most surgical units, affecting both the volume and the quality of care: different behaviors have been suggested to regulate surgical and endoscopic activity during the emergency [1-6] and a significant concern has been raised about the possibility of contagion from patients affected by COVID-19 infection during interventional procedures. It is known that surgical smoke and aerosol generated during a surgical procedure can contain viruses, which in some circumstances has led to infection [7-9]; however, no data have demonstrated the presence of SARS-CoV-2 in the smoke generated during a surgical procedure yet. Moreover, SARSCoV-2 non-respiratory transmission is still under investigation. Fecal-oral transmission has also been suggested, while viral clearance modality and its timing are not entirely understood [10-15]. Additional concerns were raised about the risk of infection associated with the use of laparoscopy. It has therefore been suggested to reduce the working pressure during abdominal laparoscopy to a minimum and some have also questioned if laparoscopy should be used at all during the pandemics. National guidelines have indeed advised to consider alternative treatments, whenever possible, underlying the suspect of an increased risk of contamination for

Lorenzo Cobianchi

Lorenzo.cobianchi@unipv.it

1 Dipartimento di Scienze Clinico Chirurgiche, Diagnostiche e Pediatriche, Università Degli Studi Di Pavia, Pavia, Italy

2 Fondazione IRCCS Policlinico San Matteo General Surgery, Pavia, Italy

3 General, Emergency and Trauma Surgery Department, Pisa University Hospital, Pisa, Italy

4 Emergency and Trauma Surgery, Maggiore Hospital, Parma, Italy laparoscopic procedures due to the aerosol diffusion in the OR environment.

Protection of any care-giver and of the surgical team is and must remain a priority. That involves comprehensive measures aimed to prevent established as well as hypothetical risk [16]. Nonetheless we should in parallel pay our attention to assess the size of the risk, recognize precise modality of viral spread, and study patterns of viral excretion in order to eventually provide our patients the same standard of quality surgery as before. Our practice must be driven by indications which, in turn, should be based on facts. Sampling peritoneal fluid during an open or a laparoscopic procedure is a relatively simple maneuver. However, that not necessarily reflects the size of the risk associated with laparoscopy, due to the related aerosol formation and of its possible diffusion in the OR environment. The possibility to sample the intraperitoneal gas would provide useful information to better understand the pattern of diffusion of COVID-19 and whether the virus is present in the peritoneal cavity and in the pneumoperitoneum of infected patients.

In this report, we describe a simple and easily reproducible method to sample fluid material obtained from the pneumoperitoneum during a laparoscopic procedure. Using commonly procurable, low-cost materials, it is possible to create hydrosol from outflowing gas and smoke, without increasing any chance of contamination for the OR team, nor increasing the duration of the procedure.

Taking forward the already described use of a ventilation machine filter [16], to limit the potential contamination risk of a laparoscopic procedure, we here suggest adding an intermediate cooling circuit to induce gas condensation and precipitation. The liquid obtained is considered as a good approximation of aerosol produced during a procedure and it can be collected for laboratory tests, such as RT-PCR and viral cultures [17, 18].

Needed materials and instructions for assembling are indicated in Fig. 1. The 150-cm IV tube must be pasted 

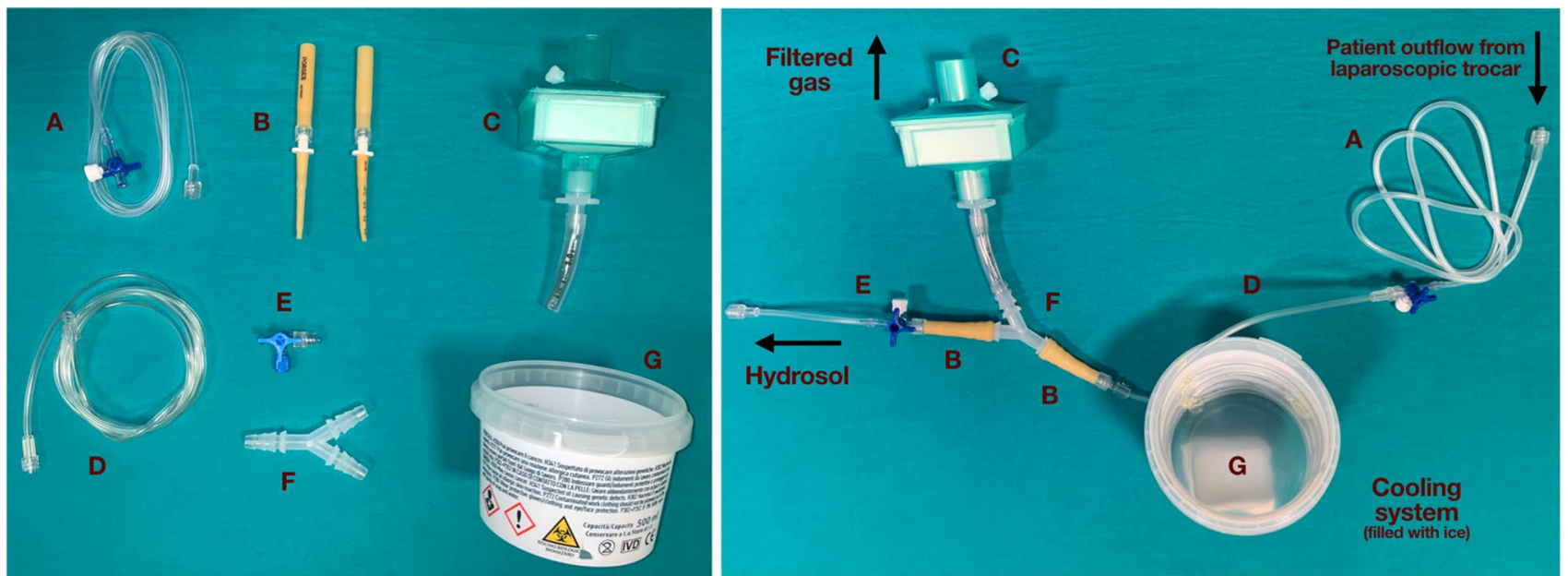

Fig. 1 Material and assembled circuit: A 3-Way stopcock with 50-cm tube (sterile); B Universal connector; C Mechanical filter connected to the end of 8.0-mm OT-tube; D IV tube $150 \mathrm{~cm}$; E 3-Way stopcock; F Y connector; G Histology specimen container $500 \mathrm{ml}$ (filled with ice)

inside the container (cyanoacrylate or glue gun), forming a descending serpentine: this will facilitate the dropping of the hydrosol. The flow resistance offered by the circuit and the filter itself is, in our experience, adequate to maintain a proper pneumoperitoneum pressure (10-12 $\mathrm{mmHg}$ ) even when the circuit is open, and it allows gas transit. From a one hour and a half long procedure, we obtained, with the almost constant filtered flow, 4-5 $\mathrm{ml}$ of hydrosol. We suggest using sterile technique to connect the 3-way stopcock with 50-cm IV tube to the trocar, so to avoid contamination of the surgical field. After the procedure, the circuit should be closed at the ends and the hydrosol collected with maximal attention. The system is for single use only and it should be discarded according to hospital indications.

The battle against the SARS-Cov-2 pandemic is still ongoing. In the absence of vaccines or effective drug treatments, it cannot be forecast how long the healthcare system will need to cope with it in managing inpatient and outpatient services [19]. Our duty, as healthcare professionals, is to protect ourselves and our co-workers most rationally and effectively possible [20]. Such an aim can be obtained by increasing and sharing the available knowledge about the disease. At the same time, it is our responsibility to guarantee the highest standards of care, among all minimal invasiveness. We do hope that this method will help to obtain new data, so to quantify exposure risks, improve protection strategies, and explore known issues about the physiopathology of SARS-Cov-2.

Acknowledgements The authors would like to thank the whole personnel of the operating compartment (particularly to Stefano Pagani, Giorgia Cassar, Elisa Bertucci, Simone Meacci and Giuseppe Dal Canto) of Pisa University Hospital, for the precious help in testing the device.
Funding This research received no specific grant from any funding agency in the public, commercial, or not for profit sectors.

\section{Compliance with ethical standards}

Disclosures Drs. E. Cicuttin, L. Cobianchi, F. Catena, M. Chiarugi, F. Coccolini, and A. Pietrabissa have no conflicts of interest or financial ties to disclose.

\section{References}

1. Di Saverio S, Pata F, Gallo G, Carrano F, Scorza A, Sileri P, Smart N, Spinelli A, Pellino G (2020) Coronavirus pandemic and Colorectal surgery: practical advice based on the Italian experience. Color Dis. https://doi.org/10.1111/codi.15056

2. Ciavattini A, Delli Carpini G, Giannella L, De Vincenzo R, Frega A, Cattani P, Boselli F, Sopracordevole F, Barbero M (2020) Expert consensus from the Italian Society for Colposcopy and Cervico-Vaginal Pathology (SICPCV) for colposcopy and outpatient surgery of the lower genital tract during the COVID-19 pandemic. Int J Gynaecol Obstet. https://doi.org/10.1002/ijgo.13158

3. Coccolini F, Perrone G, Chiarugi M, Di Marzo F, Ansaloni L, Scandroglio I, Marini P, Zago M, De Paolis P, Forfori F, Agresta F, Puzziello A, D’Ugo D, Bignami E, Bellini V, Vitali P, Petrini F, Pifferi B, Corradi F, Tarasconi A, Pattonieri V, Bonati E, Tritapepe L, Agnoletti V, Corbella D, Sartelli M, Catena F (2020) Surgery in COVID-19 patients: operational directives. World J Emerg Surg. https://doi.org/10.1186/s13017-020-00307-2

4. Sociedad Española de Patología Digestiva (2018) Recommendations by the SEPD and AEG, both in general and on the operation of gastrointestinal endoscopy and gastroenterology units, concerning the current SARS-CoV-2 pandemic (March, 18). Rev Esp Enferm Dig. https://doi.org/10.17235/reed.2020.7052/2020

5. Forrester JD, Nassar AK, Maggio PM, Hawn MT (2020) Precautions for operating room team members during the COVID-19 pandemic. J Am Coll Surg. https://doi.org/10.1016/j.jamcollsur g.2020.03.030

6. Chiu PWY, Ng SC, Inoue H, Reddy N, Hu EL, Cho JY, Ho LKY, Hewett DG, Chiu HM, Rerknimitr R, Wang HP, Ho SH, Seo DW, 
Goh KL, Tajiri H, Kitano S, Chan FKL (2020) Practice of endoscopy during COVID-19 pandemic: position statements of the Asian Pacific Society for Digestive Endoscopy (APSDE-COVID statements). Gut. https://doi.org/10.1136/gutjnl-2020-321185

7. Kwak HD, Kim S-H, Seo YS, Song K-J (2016) (2016) Detecting hepatitis B virus in surgical smoke emitted during laparoscopic surgery. Occup Environ Med 73(12):857-863. https://doi. org/10.1136/oemed-2016-103724

8. Zhou Q, Hu X, Zhou J, Zhao M, Zhu X, Zhu X (2019) (2019) Human papillomavirus DNA in surgical smoke during cervical loop electrosurgical excision procedures and its impact on the surgeon. Cancer Manag Res 11:3643-3654. https://doi.org/10.2147/ CMAR.S201975

9. Barrett WL, Garber SM (2003) (2003) Surgical smoke: a review of the literature. Is this just a lot of hot air? Surg Endosc 17(6):979987. https://doi.org/10.1007/s00464-002-8584-5

10. Ling Y, Xu S-B, Lin Y-X, Tian D, Zhu Z-Q, Dai F-H, Wu F, Song Z-G, Huang W, Chen J, Hu BJ, Wang S, Mao E-Q, Zhu L, Zhang W-H, Lu H-Z (2020) Persistence and clearance of viral RNA in 2019 novel coronavirus disease rehabilitation patients. Chin Med J (Engl). https://doi.org/10.1097/CM9.0000000000000774

11. Goh GK-M, Dunker AK, Foster JA, Uversky VN (2020) Shell disorder analysis predicts greater resilience of the SARS-CoV-2 (COVID-19) outside the body and in body fluids. Microb Pathog. https://doi.org/10.1016/j.micpath.2020.104177

12. Gu J, Han B, Wang J (2020) COVID-19: gastrointestinal manifestations and potential fecal-oral transmission. Gastroenterology. https://doi.org/10.1053/j.gastro.2020.02.054

13. Chen C, Gao G, Xu Y, Pu L, Wang Q, Wang L, Wang W, Song Y, Chen M, Wang L, Yu F, Yang S, Tang Y, Zhao L, Wang H, Wang Y, Zeng H, Zhang F (2020) SARS-CoV-2-positive sputum and feces after conversion of pharyngeal samples in patients with COVID-19. Ann Intern Med. https://doi.org/10.7326/M20-0991

14. Lescure F-X, Bouadma L, Nguyen D, Parisey M, Wicky PH, Behillil S, Gaymard A, Bouscambert-Duchamp M, Donati F, Le Hingrat Q, Enouf V, Houhou-Fidouh N, Valette M, Mailles A, Lucet JC, Mentre F, Duval X, Descamps D, Malvy D, Timsit JF, Lina B, van-der-Werf S, Yazdanpanah Y (2020) Clinical and virological data of the first cases of COVID-19 in Europe: a case series. Lancet Infect Dis. https://doi.org/10.1016/S1473 -3099(20)30200-0

15. Rothan HA, Byrareddy SN (2020) The epidemiology and pathogenesis of coronavirus disease (COVID-19) outbreak. J Autoimmun 109:102433. https://doi.org/10.1016/j.jaut.2020.102433

16. Mintz Y, Arezzo A, Boni L, Chand M, Brodie R, Fingerhut A, Technology Committee of the European Association for Endoscopic Surgery (2020) A low cost, safe and effective method for smoke evacuation in laparoscopic surgery for suspected coronavirus patients. Ann Surg. https://doi.org/10.1097/SLA.0000000000 003965

17. https://www.who.int/docs/default-source/coronaviruse/protocolv2-1.pdf.

18. Corman VM, Landt O, Kaiser M, Molenkamp R, Meijer A, Chu DKW, Bleicker T, Brünink S, Schneider J, Schmidt ML, Mulders DGJC, Haagmans BL, van der Veer B, van den Brink S, Wijsman L, Goderski G, Romette JL, Ellis J, Zambon M, Peiris M, Goossens H, Reusken C, Koopmans MPG, Drosten C (2020) Detection of 2019 novel coronavirus (2019-nCoV) by real-time RT-PCR. Euro Surveill. https://doi.org/10.2807/1560-7917. ES.2020.25.3.2000045

19. Xu S, Li Y (2020) Beware of the second wave of COVID-19. Lancet (London, England). https://doi.org/10.1016/S0140 $-6736(20) 30845-X$

20. Coccolini F, Sartelli M, Kluger Y, Pikoulis E, Karamagioli E, Moore EE, Biffl WL, Peitzman A, Hecker A, Chirica M, Damaskos D, Ordonez C, Vega F, Fraga GP, Chiarugi M, Di Saverio S, Kirkpatrick AW, Abu-Zidan F, Chicom Mefire A, Leppaniemi A, Khokha V, Sakakushev B, Catena R, Coimbra R, Ansaloni L, Corbella D, Catena F (2020) COVID-19 the showdown for mass casualty preparedness and management: the Cassandra Syndrome. World J Emerg Surg 15(1):26. https://doi.org/10.1186/s1301 7-020-00304-5

Publisher's Note Springer Nature remains neutral with regard to jurisdictional claims in published maps and institutional affiliations. 